\title{
ACTIVITIES OF INDIVIDUAL INVESTORS AND INSTITUTIONS OF JOINT INVESTMENT IN THE SECURITIES MARKET OF UKRAINE: MACROECONOMIC ASPECT
}

\author{
Yuliia Kovalenko', Tatiana Bilovus ${ }^{2}$
}

\begin{abstract}
The subject of the study is the macroeconomic indicators of individual investors and collective investment institutions in the securities market of Ukraine. The purpose of the article is to summarize and analyze the performance of individual investors and collective investment institutions in the securities market of Ukraine. Methodology. The set of methods of scientific cognition is applied in the work, which gave the opportunity to realize the conceptual unity of scientific research. Economic-statistical, calculation-analytical, system-functional and graphic methods, methods of factor, structural and formal-logical analysis made it possible to study and analyze the performance of individual investors and collective investment institutions. Research findings. The activities of individual investors and collective investment institutions are characterized by low development rates, primarily due to Ukraine's internal problems, which have existed in the country for a long time and are usually reflected in the development of SM s and investors' fear of investing in securities. All these reasons cause distrust of both Ukrainian and foreign investors in the SM, reduce the investment attractiveness of the SM instruments. In our opinion, the low results of investment processes carried out with the participation of MII are caused by the predominance of receivables, cash, other investments, etc. in the assets of MII. After all, this situation is not typical for developed SMs. Therefore, in parallel, there is a reduction in the market value, narrowing the number of available financial instruments on the SM. Value/originality. These studies will provide a better understanding of the financial situation in the securities market, the current situation regarding the functioning of market participants and can be useful in making strategic decisions and actions for further development of the securities market in Ukraine.
\end{abstract}

Key words: securities market, investors, collective investment institutions, securities, investment process.

JEL Classification: G11, G12, G23, O16, P33, P34

\section{Introduction}

Investment processes in the securities market (hereinafter - SM) are carried out effectively only when all the subjects of SM - participants in investment processes interact and cooperate productively. World practice shows the extraordinary role of all, without exception, the subjects of the SM in ensuring its effective functioning. The subjects of the SM, and hence the participants in investment processes on it include: issuers (including foreign) or persons who have issued non-equity securities; securities investors; institutional investors; professional stock market participants; association of professional stock market participants. Given the low level of development of the securities market of Ukraine, it is extremely important to study the performance of such securities market entities as individual investors and collective investors, namely - collective investment institutions. In this regard, we set the following research tasks: to study and analyze the annual reports of the National Commission on Securities and Stock Market for 2015-2019; to study the main macroeconomic indicators of individual investors and collective investment institutions; explore the main problems of development of individual investors and collective investment institutions in the securities market, as well as possible ways to solve them. The researched material in this

\footnotetext{
Corresponding author:

${ }^{1}$ University of the State Fiscal Service of Ukraine, Ukraine.

E-mail: kovalenko0202@ukr.net

ORCID: https://orcid.org/0000-0002-5678-3185

${ }^{2}$ State Educational and Scientific Institution "Academy of Financial Management", Ukraine.

E-mail: tatianabilovus@ukr.net

ORCID: https://orcid.org/0000-0003-2542-5614
} 
article we present in a logical sequence: first we demonstrate the generalized by us with the help of economic-statistical, calculation-analytical, system-functional and graphic methods analytical data on the activities of individual investors and collective investment institutions at SM for 2015-2019, and then we provide our conclusions about the problems of development of the studied subjects of SM development and suggest ways to develop these problems.

\section{Activities of investors in the securities market of Ukraine}

An extremely important entity, without which the operation of the SM is impossible, is the investor. According to Art. 2 of the Law of Ukraine "On Securities and Stock Market" investors in securities are individuals and legal entities, residents and non-residents who have acquired ownership of securities in order to obtain income from invested funds and / or acquire the relevant rights granted to the owner of securities securities in accordance with the law (On Securities, 2006).

The NCSSM annual reports for 2015-2019 (National Commission, 2020) on investments in SM indicate that investors are not only residents, ie persons located in Ukraine, but also nonresidents - persons with location outside Ukraine. Indicators of interest of domestic and foreign investors in Ukrainian assets are pessimistic, in particular, in 2017 there was a significant decline in their interest in investing in securities compared to 2016 by 1658.86 billion UAH or $78 \%$ (Table 1 ).

At the same time, the volume of trades with residents decreased in 2017 by UAH 1301.22 billion or $78 \%$, and with the participation of non-residents there is an even more significant decrease in investment in securities, which is 357.64 billion
UAH or $86.5 \%$. The share of transactions involving non-residents for the analyzed period varied increased from $15.88 \%$ in 2015 to $19.43 \%$ in 2016 , then decreased to $11.88 \%$ in 2017 , increased in 2018 to $15.28 \%$.

During 2015-2017, the SM showed a significant outflow of foreign capital, ie foreign investors sold more Ukrainian securities than they bought. Thus, in 2016, the balance of non-residents 'investments in the economy of Ukraine through SM instruments reached UAH -84.88 billion, which is characterized by a further increase in the negative balance compared to the previous year by UAH 62.1 billion or $272.61 \%$. In 2017 , this figure improved slightly and amounted to UAH - 43.26 billion, but, as we can see, also with a negative value, which only confirms the low investment attractiveness of the SM for foreign investors. However, 2018-2019 are marked by an improvement in the inflow of foreign capital to Ukraine due to non-residents 'investments in securities on the SM, which is positioned as a positive balance of non-residents' investments in the Ukrainian economy through SM instruments.

In general, assessing the intensity of investment processes in the SM of Ukraine, which are associated with investing in securities (Table 2), it should be noted that in 2015-2017 the dynamics of tori at the SM is declining (in 2016 compared to in 2015 by $2.08 \%$, in 2017 compared to 2016 by $77.97 \%$ ). This situation is explained by the negative impact on the functioning of the SM of Ukraine, and hence on the implementation of investment processes in it, political and general economic factors in the country. In 2018-2019, there is a positive trend of growth in trading on $\mathrm{SM}$, which is marked by outpacing GDP growth in these years (growth in trading on SM in 2018 was

Table 1

Volume of trades on SM of Ukraine with the participation of residents and non-residents in 2015-2019, UAH billion

\begin{tabular}{|c|c|c|c|c|c|c|}
\hline Years & $\begin{array}{c}\text { Volume of } \\
\text { trades with the } \\
\text { participation of } \\
\text { residents }\end{array}$ & $\begin{array}{c}\text { Share of } \\
\text { transactions with } \\
\text { residents, } \%\end{array}$ & $\begin{array}{c}\text { Volume of trades } \\
\text { with non- } \\
\text { residents }\end{array}$ & $\begin{array}{c}\text { Share of } \\
\text { transactions } \\
\text { involving non- } \\
\text { residents, } \%\end{array}$ & $\begin{array}{c}\text { Non-residents' } \\
\text { investment } \\
\text { balance }\end{array}$ & $\begin{array}{c}\text { The total volume } \\
\text { of trades on the } \\
\text { RCP }\end{array}$ \\
\hline 2015 & 1827,55 & 84,12 & 345,12 & 15,88 & $-22,8$ & 2172,67 \\
\hline 2016 & 1714,23 & 80,57 & 413,32 & 19,43 & $-84,88$ & 2127,55 \\
\hline 2017 & 413,01 & 88,12 & 55,68 & 11,88 & $-43,26$ & 468,69 \\
\hline 2018 & 500,36 & 84,72 & 90,22 & 15,28 & $+28,32$ & 590,58 \\
\hline 2019 & 28,9 & 3,6 & 276,1 & 96,4 & $+86,2$ & 305 \\
\hline
\end{tabular}

Source: compiled according to data (National Commission, 2020) 
Table 2

Dynamics and ratio of trading volume on SM and GDP of Ukraine in 2015-2019, UAH billion

\begin{tabular}{|c|c|c|c|c|c|c|c|c|c|}
\hline \multirow[b]{2}{*}{ Years } & \multicolumn{6}{|c|}{ Volume of trades on the securities market, UAH billion } & \multirow[b]{2}{*}{$\begin{array}{c}\text { GDP, } \\
\text { billion } \\
\text { UAH }\end{array}$} & \multirow[b]{2}{*}{$\begin{array}{l}\text { GDP } \\
\text { growth } \\
\text { rate, \% }\end{array}$} & \multirow[b]{2}{*}{$\begin{array}{l}\text { The ratio } \\
\text { of trading } \\
\text { volume on } \\
\text { the RCP to } \\
\text { GDP, \% }\end{array}$} \\
\hline & $\begin{array}{l}\text { Trading } \\
\text { volume on } \\
\text { the stock } \\
\text { market }\end{array}$ & $\begin{array}{c}\text { Growth } \\
\text { (decline) } \\
\text { of trading } \\
\text { volumes on } \\
\text { the stock } \\
\text { market, \% } \\
\end{array}$ & $\begin{array}{l}\text { Volume } \\
\text { of trading } \\
\text { on the } \\
\text { over-the- } \\
\text { counter } \\
\text { market }\end{array}$ & $\begin{array}{c}\text { Growth } \\
\text { (decline) of } \\
\text { trading volumes } \\
\text { on the over-the- } \\
\text { counter market, } \\
\%\end{array}$ & $\begin{array}{c}\text { Total } \\
\text { trading } \\
\text { volume }\end{array}$ & $\begin{array}{l}\text { Growth } \\
\text { rate } \\
\text { (decline) } \\
\text { of total } \\
\text { trades, \% }\end{array}$ & & & \\
\hline 2015 & 286,21 & - & 1886,46 & - & 2172,67 & - & 1979,5 & - & 109,76 \\
\hline 2016 & 235,4 & $-17,75$ & 1892,15 & $+0,30$ & 2127,55 & $-2,08$ & 2383,2 & $+20,39$ & 89,27 \\
\hline 2017 & 205,79 & $-12,58$ & 262,9 & $-86,11$ & 468,69 & $-77,97$ & 2982,9 & $+25,16$ & 15,71 \\
\hline 2018 & 260,87 & $+26,77$ & 329,71 & $+25,41$ & 590,58 & $+26,01$ & 3558,7 & $+19,30$ & 16,60 \\
\hline 2019 & 304,88 & $+16,87$ & 473,2 & $+43,52$ & 778,08 & $+31,75$ & 3974,6 & $+11,69$ & 19,58 \\
\hline
\end{tabular}

Source: compiled according to data (National Commission, 2020; Ukrainian Investment, 2020)

$26.1 \%$ with GDP growth of $19.3 \%$; in 2019 the increase in the volume of trades on the RCP was $16.87 \%$ with GDP growth of $11.69 \%$ ).

Non-resident investors showed unprecedented activity in the securities market in 2019. Domestic government bonds were especially popular among them. This boom in the interest of foreigners is explained by a change in government policy and focus on the availability of the Ukrainian securities market for non-resident investors. In particular, the National Bank of Ukraine introduced the possibility of conducting auctions for the sale of IGLBs on international trading platforms by making a resolution dated 10.09.2019 № 114 amendments to the Regulations on the procedure for conducting transactions related to the placement of domestic government bonds. By the way, the large-scale demand of non-residents for IGLBs became one of the determining reasons for the strengthening of the national hryvnia in 2019.

\section{Activities of mutual investment institutions}

Among investors in Ukraine, institutional investors predominate, represented by: MII, insurance companies, private pension funds, the quantitative characteristics of which are presented in Table 3.

Table data 3 allow us to conclude that the total number of MII and existing MII from 2015 to 2019 , respectively, increased by 323 companies and 19 companies. According to the NCSSM on the results of existing MII as of (National Commission, 2020):

- 31.12.2015 - 31.12.2017, MII conducted its activities in 15 regions of Ukraine, the largest number ( 764 companies in 2015; 763 companies in 2016 and 768 companies in 2017) is concentrated in Kyiv;

- On December 31, 2018, MII carried out its activities in 17 regions of Ukraine, the largest number ( 830 companies) is concentrated in Kyiv and Kyiv region;

Table 3

Quantitative characteristics of institutional investors in Ukraine for 2015-2019

\begin{tabular}{|l|c|c|c|c|c|}
\hline \multirow{2}{*}{ Institutional investor } & \multicolumn{5}{c|}{ Years } \\
\cline { 2 - 6 } & 2015 & 2016 & 2017 & 2018 & 2019 \\
\hline MII, including & 1567 & 1625 & 1701 & 1783 & 1890 \\
\hline current MII * among which & 1175 & 1179 & 1060 & 1133 & 1194 \\
\hline open & 27 & 19 & 17 & 17 & 17 \\
\hline interval & 29 & 26 & 18 & 15 & 13 \\
\hline closed & 108 & 99 & 69 & 67 & 60 \\
\hline venture & 1011 & 1035 & 956 & 1034 & 1104 \\
\hline IC & 361 & 310 & 294 & 281 & 233 \\
\hline PPF & 72 & 64 & 64 & 62 & 65 \\
\hline
\end{tabular}

* Existing MII are mutual investment funds, which according to the order of the authorized person of the Commission are recognized as meeting the requirements for the minimum amount of assets, and / or corporate investment fund, which are included in EDRISI and are not in the process of termination.

Source: compiled according to data (National Commission, 2020; Ukrainian Investment, 2020; Forenschurer, 2020) 
- On December 31, 2019, MII conducted its activities in 18 regions of Ukraine, the largest number ( 872 companies) is concentrated in Kyiv and Kyiv region.

Thus, the ability of individual and corporate investors to invest free resources in MII securities on the SM from year to year increases not only in terms of the number of MII, but also in terms of the geography of their operation. Confidence in MII is evidenced by the figures on the value of MII assets (Figure 1). Thus, as of December 31, 2019, the total assets of MII amounted to UAH 346.12 billion, which is $8.71 \%$ of Ukraine's GDP and is UAH 110.1 billion or $46.65 \%$ more than the value of MII assets in 2015. This indicates a very high level of MII development in the country over the years, especially since reforms are being actively developed and implemented, the implementation of which requires significant investment resources. In foreign countries, it is MII that helps to finance new business, new investment and innovation projects, etc to a greater extent.

Ukrainian MIIs invest a small share of their assets in securities, preferring more reliable investments in real estate, deposits of commercial banks, receivables, etc. Thus, for the period from 2015 to 2019, the share of MII investments in securities decreased from $21.78 \%$ to $10.65 \%$ (Table 4 ). MII, as a rule, are "afraid" to take risks and invest significant capital in securities, due to the speculative nature and fraud, which have become the "norm" for the
Ukrainian SM. In the investment portfolios of MII, the largest share among securities, which ranges from $51.0 \%$ in 2015 to $34.43 \%$ in 2019 , belongs to shares.

Throughout the period of MII development, the largest investors in their securities were and remain individuals, whose share according to the Ukrainian Investment Business Association in the total number of MII investors at the end of 2019 was $98.74 \%$ (Table 5).

It is also worth noting the positive dynamics of the number and share of individuals - investors in MII for 2015-2019 (from 97.79\% to $98.74 \%$ ). Investments of Ukrainian citizens predominate in interval MII because among the features of this type of investment funds is the function of "repaying" their shares at certain intervals, which is a good specification for investors of their time expectations. It should be noted that open MII, which are most sensitive to the moods and desires of investors, are also popular among individual investors.

The growth of individual investors' contributions to MII securities, in our opinion, is a manifestation of increased confidence in MII by ordinary citizens, as well as increasing the level of their financial awareness. If we analyze the trading in MII securities on the SM for 2015-2019 (Table 6), we see an unstable picture, both in general in terms of trading volumes of MII securities on the SM, and in its exchange and over-the-counter markets.

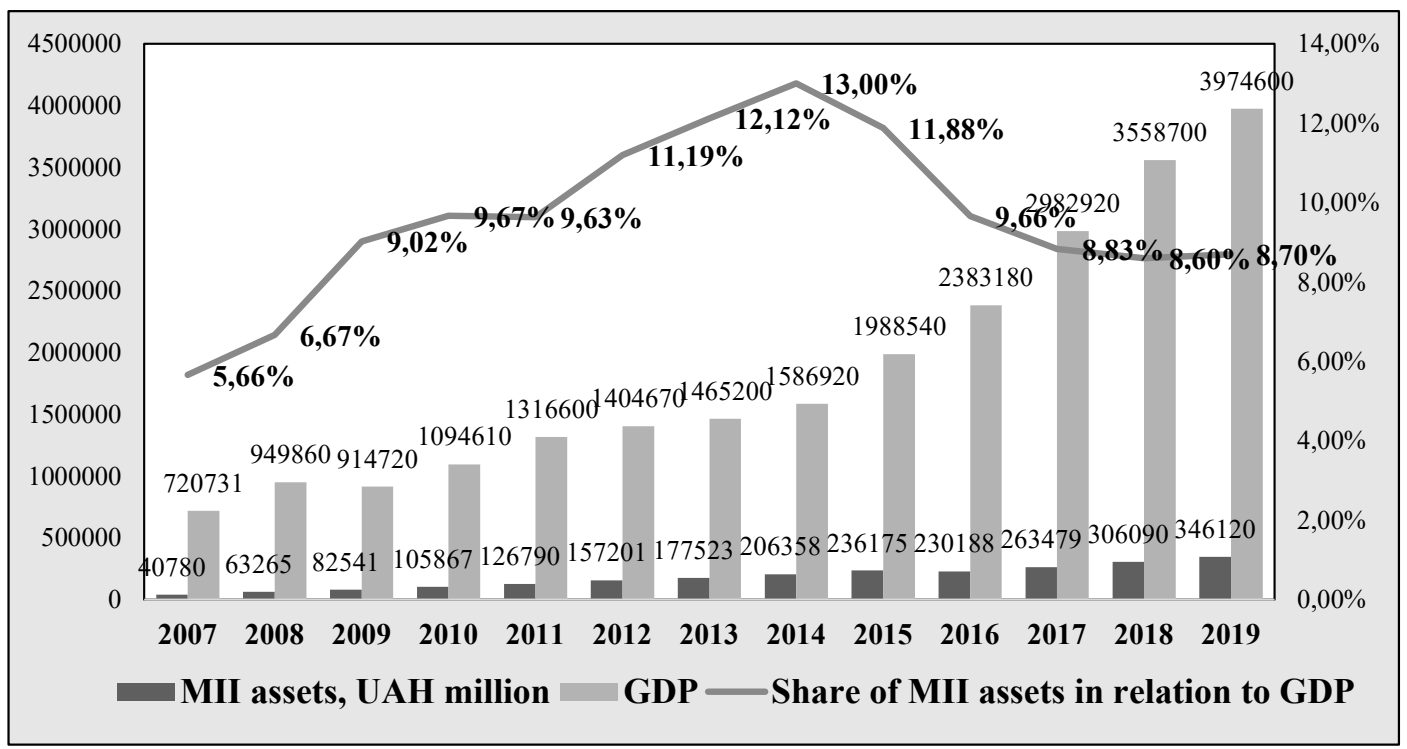

Figure 1. The ratio of MII assets to GDP

Source: built on data (State Statistics, 2020; National Commission, 2020) 
Table 4

Consolidated portfolio of MII securities by types of instruments in total MII assets in 2015-2019 (UAH million)

\begin{tabular}{|l|c|c|c|c|c|}
\hline \multirow{2}{*}{\multicolumn{1}{c|}{ Total assets }} & \multicolumn{5}{c|}{ Years } \\
\cline { 2 - 6 } & 2015 & 2016 & 2017 & 2018 & 2019 \\
\hline Securities & 51395 & 50005 & 42831,54 & 37493,44 & 36878,19 \\
\hline Promotions & 26223 & 28177 & 21621 & 17952,14 & 13065,95 \\
\hline Promissory notes & 15909 & 12654 & 11726,88 & 9258,83 & 7886,20 \\
\hline Enterprise bonds & 8899 & 8500 & 8072,86 & 8049,92 & 13316,81 \\
\hline Government securities & 292 & 432 & 552,04 & 763,24 & 745,74 \\
\hline Bond of domestic local loans & & & & & 11,58 \\
\hline Foreign government bonds & & & & & 12,33 \\
\hline Derivatives & 72 & 242 & 858,76 & 1469,31 & 1839,58 \\
\hline Other assets & 184622,06 & 180849 & 221801 & 268592,38 & 309240,52 \\
\hline Share of securities in total assets, \% & 21,78 & 21,66 & 16,19 & 12,25 & 10,65 \\
\hline Total assets & 236017,06 & 230854,29 & 264632,33 & 306085,82 & 346118,71 \\
\hline
\end{tabular}

Source: built on data (National Commission, 2020; Ukrainian Investment, 2020)

The peak year of growth in the volume of MII securities trading on the SM in the period we are analyzing is 2015 , when the trading volume reached UAH 102.68 billion. In the following years, there was a sharp decline (in 2016 by $31.45 \%$; in 2017 by $45.59 \%$ and in 2019 by $12.65 \%)$. Only 2018 is marked by an improvement in the situation, which led to an increase in MII securities trading by $18.43 \%$. The trading volumes of MII securities on the over-the-counter securities market have always exceeded the indicators of trading on the stock exchange. MII prefers to trade on the over-thecounter market because in this segment of the SM there are no strict conditions for admission to trading of securities, there are more interesting and convenient tools for investors to work, there are no commissions for participation in exchange systems. requirements of the stock market.

Due to competition with banks in attracting and accumulating investment funds, MII promise their investors greater returns than the latter can receive from bank deposits. This is the main reason why investors invest in investment funds. But at the same time promising for MII is cooperation with banking institutions, which creates new prospects for reducing the cost of banking resources, redistribution and reduction of risks, intensification of banking institutions in the securities market, consolidation of savings of individual investors into a single pool, followed by diversified investment in various projects with long-term capitalization. MII thus become effective tools for the accumulation of significant capital, the circulation of which ensures the har-monious development of the national economy.

\section{Problems of development of activity of investors and MII}

In our opinion, the low performance of individual investors and collective investment institutions is primarily due to Ukraine's internal problems, which have existed in the country for a long time and, as a rule, are reflected in the development of SM and investors' fear of investing in securities. Such problems include: unstable political and economic situation in Ukraine, high corruption, non-transparent and speculative functioning of the SM, insecurity of investors' rights, limited types of financial instruments, etc. All these reasons cause distrust of both Ukrainian and foreign investors in the SM, reduce the investment attractiveness of the SM instruments.

In our opinion, the low results of investment processes carried out with the participation of MII are caused by the predominance of receivables, cash, other investments, etc. in the assets of MII. After all, this situation is not typical for developed SMs. Therefore, in parallel, there is a reduction in the market value, narrowing the number of available financial instruments on the SM. 
Vol. 1, No. 2, 2020

Green, Blue \& Digital Economy Journal

Table 5

Number and share of MII investors by categories of condition on 31.12.2015-31.12.2019

\begin{tabular}{|c|c|c|c|c|c|c|}
\hline Funds & Open & Intervals & $\begin{array}{l}\text { Closed (except } \\
\text { venture) }\end{array}$ & $\begin{array}{l}\text { all (except } \\
\text { venture) }\end{array}$ & Venture & $\begin{array}{l}\text { All (with } \\
\text { venture) }\end{array}$ \\
\hline \multicolumn{7}{|c|}{$2015 \mathrm{p}$} \\
\hline \multicolumn{7}{|c|}{ Entities: } \\
\hline number & 30 & 41 & 393 & 464 & 4571 & 5035 \\
\hline share, $\%$ & 1,13 & 0,02 & 21,52 & 0,21 & 90,6 & 2,21 \\
\hline \multicolumn{7}{|c|}{ Individuals: } \\
\hline number & 2626 & 217865 & 1433 & 221924 & 474 & 222398 \\
\hline share, $\%$ & 98,87 & 99,98 & 78,47 & 99,79 & 9,4 & 97,79 \\
\hline \multicolumn{7}{|c|}{2016 p. } \\
\hline \multicolumn{7}{|c|}{ Entities: } \\
\hline number & 23 & 24 & 435 & 482 & 4199 & 4681 \\
\hline share, $\%$ & $1,35 \%$ & $0,01 \%$ & $8,92 \%$ & $0,18 \%$ & $89,74 \%$ & $1,79 \%$ \\
\hline \multicolumn{7}{|c|}{ Individuals: } \\
\hline number & 1671 & 250012 & 4440 & 256123 & 480 & 256603 \\
\hline share, $\%$ & $98,64 \%$ & $99,99 \%$ & $91,07 \%$ & $99,81 \%$ & $10,26 \%$ & $98,20 \%$ \\
\hline \multicolumn{7}{|c|}{2017 p. } \\
\hline \multicolumn{7}{|c|}{ Entities: } \\
\hline number & 24 & 53 & 382 & 459 & 3269 & 3728 \\
\hline share, $\%$ & $1,40 \%$ & $0,02 \%$ & $8,75 \%$ & $0,18 \%$ & $86,69 \%$ & $1,43 \%$ \\
\hline \multicolumn{7}{|c|}{ Individuals: } \\
\hline number & 1687 & 249995 & 3982 & 255664 & 502 & 256166 \\
\hline share, $\%$ & $98,60 \%$ & $99,98 \%$ & $91,25 \%$ & $99,82 \%$ & $13,32 \%$ & $98,56 \%$ \\
\hline \multicolumn{7}{|c|}{2018 p. } \\
\hline \multicolumn{7}{|c|}{ Entities: } \\
\hline number & 27 & 19 & 380 & 426 & 3276 & 3702 \\
\hline share, $\%$ & $1,64 \%$ & $0,01 \%$ & $9,08 \%$ & $0,16 \%$ & $84,94 \%$ & $1,43 \%$ \\
\hline \multicolumn{7}{|c|}{ Individuals: } \\
\hline number & 1623 & 249840 & 3802 & 255265 & 581 & 255846 \\
\hline share, $\%$ & $98,36 \%$ & $99,99 \%$ & $90,92 \%$ & $99,84 \%$ & $15,06 \%$ & $98,57 \%$ \\
\hline \multicolumn{7}{|c|}{2019 p. } \\
\hline \multicolumn{7}{|c|}{ Entities: } \\
\hline number & 23 & 18 & 345 & 386 & 2862 & 3248 \\
\hline share, \% & $1,40 \%$ & $0,01 \%$ & $9,28 \%$ & $0,15 \%$ & $78,50 \%$ & $1,26 \%$ \\
\hline \multicolumn{7}{|c|}{ Individuals: } \\
\hline number & 610 & 249836 & 3370 & 254816 & 784 & 255600 \\
\hline share, $\%$ & $98,60 \%$ & $99,99 \%$ & $90,72 \%$ & $99,85 \%$ & $21,50 \%$ & $98,74 \%$ \\
\hline
\end{tabular}

Source: compiled according to data (Ukrainian Investment, 2020)

Table 6

Dynamics of the volume of MII securities trading on the SM of Ukraine for 2015-2019, UAH billion

\begin{tabular}{|c|c|c|c|c|c|c|}
\hline \multirow[b]{2}{*}{ Years } & \multicolumn{6}{|c|}{ Volume of CII securities trading on RCP, UAH billion } \\
\hline & $\begin{array}{c}\text { Trading volume } \\
\text { on the stock } \\
\text { market }\end{array}$ & $\begin{array}{l}\text { Growth (decline) } \\
\text { of trading volumes } \\
\text { on the stock } \\
\text { market, } \%\end{array}$ & $\begin{array}{l}\text { Obsyag traded } \\
\text { on the post- } \\
\text { exchange } \\
\text { market }\end{array}$ & $\begin{array}{c}\text { The rate of growth } \\
\text { (fall) by selling at } \\
\text { the post-exchange } \\
\text { market, \% }\end{array}$ & $\begin{array}{c}\text { General trading } \\
\text { volume }\end{array}$ & $\begin{array}{l}\text { Growth rate } \\
\text { (decline) of } \\
\text { total trades, \% }\end{array}$ \\
\hline 2015 & 2,76 & - & 99,92 & - & 102,68 & - \\
\hline 2016 & 0,5 & $-81,88$ & 69,89 & $-30,05$ & 70,39 & $-31,45$ \\
\hline 2017 & 0,06 & $-88,00$ & 38,24 & $-45,29$ & 38,3 & $-45,59$ \\
\hline 2018 & 0,29 & $+383,33$ & 45,07 & $+17,86$ & 45,36 & $+18,43$ \\
\hline 2019 & 0,33 & $+13,79$ & 39,28 & $-12,85$ & 39,62 & $-12,65$ \\
\hline
\end{tabular}

Source: compiled according to data (National Commission, 2020; Ukrainian site on finance, 2020) 
There are almost no high-quality securities in Ukraine, which hinders the development of both SMs in general and the development of open-end and interval funds that invest in stocks and bonds in world practice. In this case, the main reasons that negatively affect the level of profitability of equity financial instruments include:

- reduction of dividends as a result of the decline in the issuer's profitability;

- volatility of the value of the issuer's net assets;

- decline in profitability or, even worse, unprofitability of the issuer;

- overstated value of securities at the time of purchase by the investor;

- stagnation and general decline in the functioning and development of SM.

The main factors reducing the profitability of debt securities are:

- the average interest rate on the financial market is too high;

- high inflation;

- insolvency of the issuer of debt financial instruments.

\section{Suggestions for the development of SM}

Analysis of the activities of SM entities allows us to identify several areas in the development of SM: to create a committee that would regulate the interaction and obligations of all participants in the SM; to expand the powers of the NCSSM at the SM, especially with regard to offenses at the SM; unification of exchanges, as well as the development of uniform rules for the operation of stock exchanges, in order to avoid unnecessary price speculation, interexchange contradictions and any other obstacles that hinder the effective and transparent operation of the SM; development of clear and understandable for investors, especially for small "average" investors, rules for providing services to all SM entities, in particular, stock exchanges, which would help attract additional investment in SM; an effective mechanism for protecting the rights of investors on the SM; to give SROs broader rights and powers in matters of SM regulation, etc.

\section{Conclusions}

Thus, we can talk about the low level of development of the infrastructure of the securities market, the low activity and lack of the required number of SM entities, in particular, there is an urgent need for individual and collective investors in the SM, and these are the main entities without which exist market. Also, no clear legal regulation of the activities of SM financial institutions has been developed so far, and a mechanism for clear interaction and cooperation between the state and other market participants has not been established.

The efficiency of investment processes both in this market and in the country as a whole depends on how harmoniously the SM entities will function and cooperate.

\section{References:}

National Commission on Securities and Stock Market. Retrieved September 11, 2020 from http://www.nssmc.gov.ua

Forenschurer: an online journal on technologies in the insurance, insurtech and fintech industries. Retrieved August 8, 2020 from https://forinsurer.com/

On Securities and the Stock Market: Law of Ukraine of 23.02.2006 p. № 3480-IV. Retrieved August 7, 2020 from http://zakon2.rada.gov.ua/laws/show/3480-15

State Statistics Service of Ukraine: official site. Retrieved September 17, 2020 from http://www.ukrstat.gov.ua/

Ukrainian Investment Business Association: official website. Retrieved August 15, 2020 from https://www.uaib.com.ua/

Ukrainian site on finance and investment "Ministry of Finance". Retrieved August 29, 2020 from https://index.minfin.com.ua/ua/economy/gdp/2020/ 